\title{
A Comparative Study of Electrochemical Treatment of Para-Toluic Acid (p-TA) from Aqueous Solution: Process Optimization and Sludge Analysis
}

\author{
Vishal Kumar Sandhwar $^{1}$ • Basheshwer Prasad ${ }^{1}$
}

Received: 7 October 2016/Revised: 1 February 2017 / Accepted: 2 February 2017 / Published online: 6 March 2017

(C) Springer Science+Business Media Singapore 2017

\begin{abstract}
The present study deals with the removal of paratoluic acid (p-TA) as well as chemical oxygen demand (COD) from synthetic solution. Pretreatment of aqueous solution was done by acid precipitation at different $\mathrm{pH}$ levels (3-6) and temperatures $\left(15-60{ }^{\circ} \mathrm{C}\right)$. The pretreated solution was further treated by electrocoagulation (EC) and electro-Fenton (EF) treatment technologies using iron anode and graphite cathode. Optimization of various independent operating parameters viz. initial $\mathrm{pH}(1-9)$, current density $\left(30.48-152.44 \mathrm{~A} / \mathrm{m}^{2}\right)$, electrolyte concentration (for EC) $\left(0.03-0.07 \mathrm{~mol} / \mathrm{L}\right.$ ), $\mathrm{H}_{2} \mathrm{O}_{2}$ concentration (for EF) (300-700 mg/L), and electrolysis time (10-90 min) was performed using central composite design (CCD) in response surface methodology (RSM). At optimum operating conditions, maximum removal percent of p-TA 64.83, 74.50; COD 61.27, 68.21; and energy consumption (kWh/kg COD removed) $69.71,41.60$ were obtained by EC and $\mathrm{EF}$ processes, respectively. In this study, it was observed that the EF process was more efficient than EC process based on percent removal of p-TA and COD with minimum energy consumption (E.consumption). Sludge obtained after EC and EF treatments was analyzed for various physicochemical
\end{abstract}

Highlights - Maximum percent removal of p-TA 74.50 and COD 68.21 were achieved by electro-Fenton process.

- Energy consumption was low in electro-Fenton process.

- The amount of sludge generated by electro-Fenton process was lower in volume.

- Proximity of actual and model predicted values was found.

- Removal efficiencies were strongly affected by current density and $\mathrm{pH}$.

Vishal Kumar Sandhwar

vksandhwar@gmail.com

1 Department of Chemical Engineering, Indian Institute of Technology Roorkee, Roorkee, (Uttarakhand) 247667, India characteristics like settling, point of zero charge, XRD, FTIR, SEM/EDX, and DTA/TGA.

Keywords Para-toluic acid - Acid precipitation . Electrocoagulation · Electro-Fenton · Optimization · Sludge characterization

\section{Introduction}

Purified terephthalic acid (PTA) is a xylene-based petrochemical product widely used for the manufacturing of polyethylene terephthalate bottles, polyester films, and textile fibers [1, 2]. About $3-4 \mathrm{~m}^{3}$ of wastewater (COD $\left.(5-20 \mathrm{~g} / \mathrm{L})\right)$ is generated for per ton of PTA production [3]. Wastewater generated from petrochemical industries contains a number of pollutants with very high values of chemical oxygen demand (COD). The wastewater released from a PTA manufacturing unit usually comprises various aromatic compounds such as benzoic acid (BA), para-Toluic acid (p-TA), phthalic acid (PA), terephthalic acid (TPA), and 4-carboxybenzaldehyde (4CBA) in high concentration with low concentration of methyl acetate, 4-formylbenzoic acid, and p-xylene [4-8]. The phthalate forms are highly toxic due to their endocrine disrupting ability and adverse effects on reproduction capacity as well as development of human beings [9]. Para-toluic acid is a white crystalline powder having low solubility in water; however, solubility increases in aqueous solution of sodium hydroxide $[10,11]$. It is widely used for the production of several products such as medicines, agrochemicals, pigments, pharmaceuticals, dyestuffs, and optical brighteners [12]. Although p-TA has wide applications, intake in high amount is very dangerous for the human body due to its hazardous and toxic nature [13]. It can be a reason for the abatement in epididymal oligozoospermia [14]. Because of the highly toxic 
nature of BA, p-TA, and TPA, the US Environmental Protection Agency (USEPA) included these compounds in the list of priority pollutants [14-16]. No specific discharge limit for $\mathrm{p}$-Toluic acid has been proposed by the pollution regulating agencies in India. The permissible discharge limit of COD $<250 \mathrm{mg} / \mathrm{L}$ has been prescribed by the environmental regulating agencies for petrochemical wastewaters into surface waters [17] in India. Hence, it is very necessary to determine the effective treatment technologies for PTA wastewater to achieve the prescribed discharge standards. In the recent years, numerous treatment technologies like adsorption [18-21], electrochemical methods [22, 23], coagulationflocculation [3, 24, 25], thermochemical precipitation [26], crystallization [27], and oxidation process [28, 29] have been used for PTA wastewater treatment. Electrochemical technologies like electrocoagulation as well as electro-Fenton are the efficient techniques used for wastewater treatment in the last few years.

In electrocoagulation (EC), generation of coagulant takes place in situ by the electrolytic oxidation of an anode material that neutralizes the pollutants present in wastewater by mutual collision and are agglomerated, followed by sedimentation [30]. The EC process includes the following steps: (a) electrolytic reactions at the surfaces of electrodes, (b) in-situ oxidation of metallic ions and eventual precipitation of metal hydroxides in the electrolytic solution, (c) adsorption of colloidal and soluble pollutants on the coagulant surface [31], and (d) pollutant removal through sedimentation or flotation [32]. The reactions occurring at electrodes are as follows:

At anode:

$\mathrm{Fe}_{(\mathrm{s})} \rightarrow \mathrm{Fe}^{2+}{ }_{(\mathrm{aq})}+2 \mathrm{e}^{-}$

At cathode:

$2 \mathrm{H}_{2} \mathrm{O}+2 \mathrm{e}^{-} \rightarrow 2 \mathrm{OH}^{-}{ }_{(\text {aq })}+\mathrm{H}_{2}(\mathrm{~g})$

Electro-Fenton (EF) is one of the most popular electrochemical advanced oxidation processes as well as an ecofriendly method for water remediation based on Fenton's reaction chemistry [33]. EF process has two distinct configurations. Fenton reagents are added to the reactor from outside in the first configuration while in the second design, only hydrogen peroxide $\left(\mathrm{H}_{2} \mathrm{O}_{2}\right)$ is added to the reactor from outside, and ferrous ions are generated from sacrificial iron anode [34]. The following chain reactions show the EF process $[35,36]$ :

$\mathrm{H}_{2} \mathrm{O}_{2}+\mathrm{Fe}^{2+} \rightarrow \mathrm{Fe}^{3+}+\mathrm{OH}^{-}+{ }^{\circ} \mathrm{OH}$

$\mathrm{RH}+{ }^{\circ} \mathrm{OH} \rightarrow \mathrm{R}^{\cdot}+\mathrm{H}_{2} \mathrm{O}$

where RH is organic pollutant:

$\mathrm{R}^{\cdot}+\mathrm{Fe}^{3+} \rightarrow \mathrm{R}^{+}+\mathrm{Fe}^{2+}$
$\mathrm{Fe}^{2+}+{ }^{\circ} \mathrm{OH} \rightarrow \mathrm{Fe}^{3+}+\mathrm{OH}^{-}$

In the present study, treatment of p-TA from aqueous solution was done through acid precipitation followed by electrocoagulation and electro-Fenton methods separately using iron as anode and graphite as cathode. The electrochemical studies were done by using the central composite design (CCD) of response surface methodology (RSM) in Design Expert Software (DES). RSM is an efficient statistical tool for the optimization of industrial processes [37]. Here, it was used for the optimization of various electrochemical parameters viz. $\mathrm{pH}$, current density, electrolyte concentration or $\mathrm{H}_{2} \mathrm{O}_{2}$ concentration, and time for maximum removal of COD and $\mathrm{p}$ TA with minimum electrical energy consumption (E.consumption).

\section{Materials and Methods}

\section{Chemicals}

All the chemicals used during the entire study were of analytical grade (AR). Para-Toluic acid ( $99 \%$ purity), sodium chloride $(\mathrm{NaCl})$, and sodium sulfate $\left(\mathrm{Na}_{2} \mathrm{SO}_{4}\right)$ were purchased from Loba Chemie Pvt. Ltd., Mumbai (India). Hydrogen peroxide $\left(\mathrm{H}_{2} \mathrm{O}_{2}\right)(30 \% \mathrm{w} / v)$ was supplied by S.D.Fine-Chem Limited Mumbai (India). Sulfuric acid $\left(\mathrm{H}_{2} \mathrm{SO}_{4}\right)$, potassium dichromate $\left(\mathrm{K}_{2} \mathrm{Cr}_{2} \mathrm{O}_{7}\right)$, sodium hydroxide $(\mathrm{NaOH})$, methanol $\left(\mathrm{CH}_{3} \mathrm{OH}\right)$, isopropyl alcohol $\left(\mathrm{C}_{3} \mathrm{H}_{8} \mathrm{O}\right)$, silver sulfate $\left(\mathrm{Ag}_{2} \mathrm{SO}_{4}\right)$ acetic acid $\left(\mathrm{CH}_{3} \mathrm{COOH}\right)$, and mercury (II) sulfate $\left(\mathrm{HgSO}_{4}\right)$ were procured from Ranbaxy Fine Chemicals Limited, New Delhi (India).

\section{Wastewater Sampling and Analysis}

Stock solution of para-Toluic acid of $1000 \mathrm{mg} / \mathrm{L}$ was synthetically prepared at laboratory. All the reagents and wastewater samples were preserved at $4{ }^{\circ} \mathrm{C}$ to avoid biodegradation and growth of microorganisms. The initial concentration of p-TA $(500 \mathrm{mg} / \mathrm{L})$ was taken according to previous studies [24, 38, 39]. Initially, the COD of wastewater was found to be $1049 \mathrm{mg} / \mathrm{L}$. Wastewater characteristics like $\mathrm{pH}$ and COD were determined in accordance with the standard methods [40]. Concentrations of $\mathrm{p}$-TA and COD values were analyzed by HPLC (Waters, USA) using a UV detector (Waters 2487 absorbance detector, USA) set at $240 \mathrm{~nm}$ [22, 41, 42] and a COD analyzer (Aqualytic, Germany), respectively. Samples were filtered through nylon syringe filter $(0.21 \mu \mathrm{m})$ before each analysis. The HPLC system was operated at ambient temperature with C18 column and mobile phase (solution of $91 \%$ Millipore water, $7 \%$ isopropyl alcohol and $2 \%$ acetic acid with $1.2 \mathrm{~mL} / \mathrm{min}$ flow rate) in isocratic mode [43]. Ferrous ion $\left(\mathrm{Fe}^{2+}\right)$ concentration was measured through spectrophotometric 
Fig. 1 Schematic diagram of experimental setup for electrochemical treatment

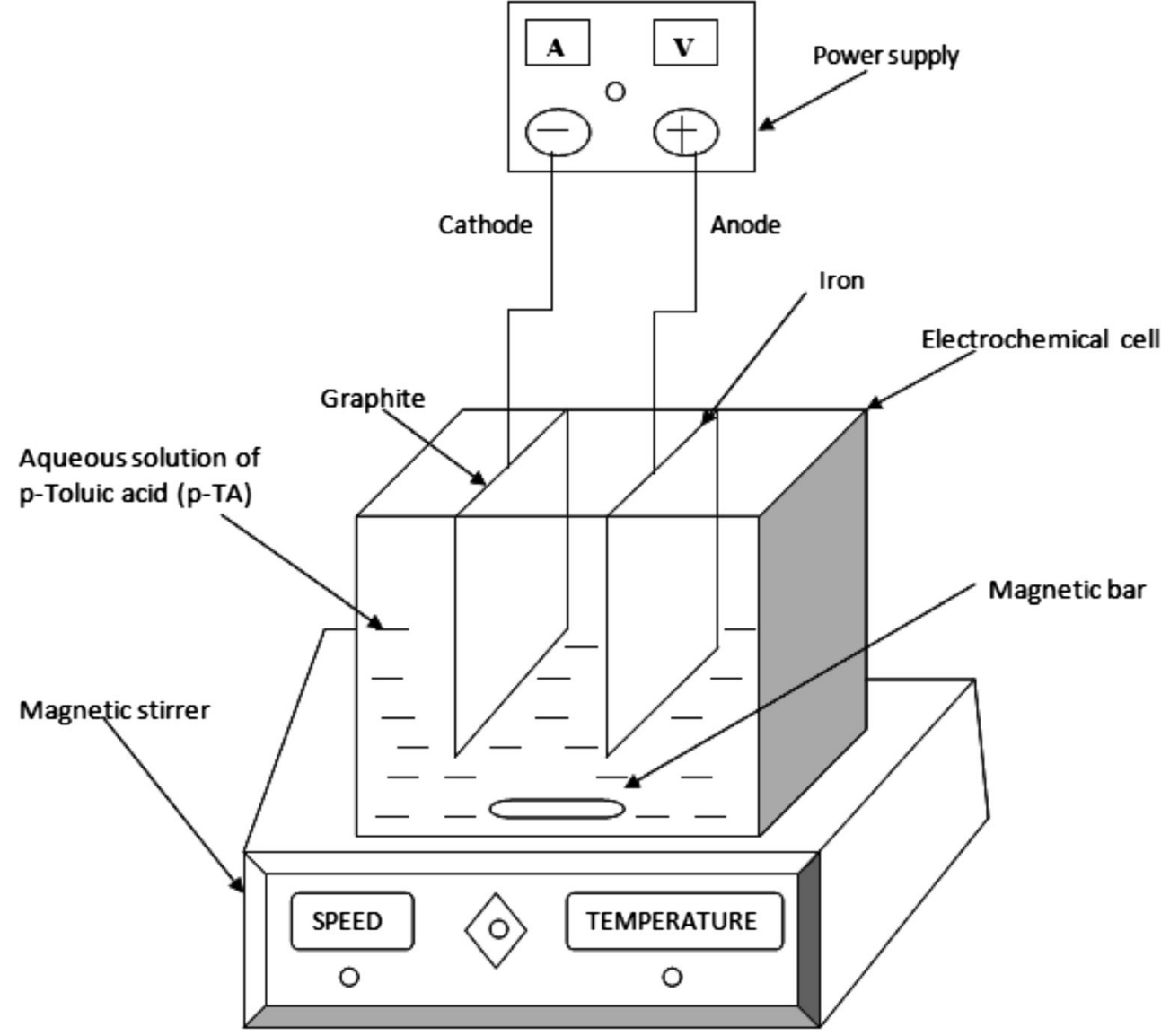

method [40]. Percent removal of p-TA, COD, and E.consumption $\left(\mathrm{kWh} / \mathrm{kg} \mathrm{COD}_{\text {removed }}\right)$ were calculated by the following equations:

\%Removal of p-TA and COD $=\frac{c_{i}-c_{f}}{c_{i}} \times 100$

where $\mathrm{C}_{\mathrm{i}}$ and $\mathrm{C}_{\mathrm{f}}$ are the initial and final concentrations of p-TA and COD.

E.consumption $(\mathrm{kWh} / \mathrm{kgCOD}$ removed $)$

$$
=\frac{\mathrm{VIT} \times 100}{(\% \text { Removal of } \mathrm{COD}) \mathrm{C}_{\mathrm{CODi}} \times \mathrm{V}_{\mathrm{S}}} \times 1000
$$

where V, I, T, and $\mathrm{V}_{\mathrm{S}}$ are the voltage, current (amp), time (hour), and volume of the solution (liter), respectively [44].

Table 1 Operating parameters and their levels obtained from the statistical software for EC and EF processes

\section{Central composite design characteristics}

Levels Parameter (range)

\begin{tabular}{ll}
\hline $\mathrm{X}_{1}$ & $\mathrm{X}_{2}$ \\
$\mathrm{pH}$ & $\mathrm{CD}\left(\mathrm{A} / \mathrm{m}^{2}\right)$ \\
$(1 \rightarrow 9)$ & $(30.48 \rightarrow 152.44)$
\end{tabular}

\begin{tabular}{lll}
$\mathrm{X}_{3}$ & & $\begin{array}{c}\mathrm{X}_{4} \\
\text { Time }(\min )\end{array}$ \\
\hline$\left(\mathrm{X}_{3}\right)_{\mathrm{EC}}$ & $(10 \rightarrow 90)$ \\
$\mathrm{Na}_{2} \mathrm{SO}_{4}$ concentration $\left(\frac{m o l}{L}\right)$ & $\left(\mathrm{X}_{3}\right)_{\mathrm{EF}}$ & \\
$(0.03 \rightarrow 0.07)$ & $\mathrm{H}_{2} \mathrm{O}_{2}$ concentration $\left(\frac{m g}{L}\right)$ &
\end{tabular}

\begin{tabular}{llllll}
\hline$-2(-\alpha)$ & 1 & 30.48 & 0.03 & 300 & 10 \\
-1 & 3 & 60.97 & 0.04 & 400 & 30 \\
0 & 5 & 91.46 & 0.05 & 500 & 50 \\
+1 & 7 & 121.95 & 0.06 & 600 & 70 \\
$+2(\alpha)$ & 9 & 152.44 & 0.07 & 700 & 90 \\
\hline
\end{tabular}




\section{Experimental Procedure}

Acid precipitation experiment was done through mixing of sulfuric acid $(1 \mathrm{~N})$ to the aqueous solution at different temperatures to adjust the initial $\mathrm{pH}\left(\mathrm{pH}_{0}=6.2\right)$ of wastewater at $\mathrm{pH}$ levels 6 , 5,4 , and 3. Precipitated solution was allowed to settle for $4 \mathrm{~h}$. Then, the supernatant was filtered and further treated by electrochemical processes. The entire electrochemical experiments were performed in a rectangular Plexiglas batch cell with a capacity of $1.6 \mathrm{~L}$. Iron anode $(100 \mathrm{~mm} \times 80 \mathrm{~mm} \times 1 \mathrm{~mm})$ and graphite cathode $(100 \mathrm{~mm} \times 80 \mathrm{~mm} \times 3 \mathrm{~mm})$ with an effective electrode area into the solution $\left(131.2 \mathrm{~cm}^{2}\right)$ were used during both electrochemical processes for treatment of $1 \mathrm{~L}$ of solution. The gap between parallel electrodes was $2 \mathrm{~cm}$. Between each successive runs, electrodes were cleaned with $\mathrm{H}_{2} \mathrm{SO}_{4}$ solution $(5 \% \mathrm{v} / \mathrm{v})$ for next experiment. The schematic diagram for electrochemical treatment is shown in Fig. 1. Some initial test runs were conducted to determine the operating parameter range for both processes. Table 1 shows the operating parameter range. Direct current $(0-4 \mathrm{~A})$ and voltage $(0-35 \mathrm{~V})$ were used to power the parallel electrodes. Both the $\mathrm{EC}$ and $\mathrm{EF}$ processes were conducted at room temperature $\left(25 \pm 2{ }^{\circ} \mathrm{C}\right)$ and atmospheric pressure. The desired amount of hydrogen peroxide $\left(\mathrm{H}_{2} \mathrm{O}_{2}\right)$ was added to the reactor before switching on the power supply during $\mathrm{EF}$ treatment.

\section{Results and Discussion}

\section{Effect of Acid Precipitation on Percent Removal of P-TA and COD}

p-TA was present in ionized state in the aqueous solution, as the $\mathrm{pKa}$ value for $\mathrm{p}-\mathrm{TA}$ is 4.36 . The acid gets deionized by reduction of the $\mathrm{pH}$ (initial $\mathrm{pH} 6.8$ ) of wastewater. The ionic product value and solubility product constant (Ksp) for p-TA are $4.395 \times 10^{-5}$ and $8.714 \times 10^{-6}$, respectively [45]. Hydrogen ion concentration increases in the solution with decrease in $\mathrm{pH}$, and due to the common-ion (hydrogen ions) effect, the ionic product value of p-TA surpasses its solubility product value resulting acid precipitation [46]. The precipitated solution was allowed to settle for $4 \mathrm{~h}$. After settling, supernatant was filtered through Whatman filter paper $(11 \mu \mathrm{m})$. Precipitation causes reduction in the concentration of $\mathrm{p}-\mathrm{TA}$, and the COD value of the supernatant by $38.2 \%$ and $33.1 \%$, respectively, at optimum $\mathrm{pH} 3$ and temperature of $15^{\circ} \mathrm{C}$ as shown in Fig. 2a, b. The filtered supernatant was further treated by both electrochemical processes.

\section{Effect of pH on Percent Removal of P-TA, COD, and E.Consumption}

$\mathrm{pH}$ plays a vital role in influencing the performance of $\mathrm{EC}$ and EF processes. The effect of $\mathrm{pH}$ on removal efficiencies depends on the formation of complexes. In EC process, complexes form by conversion of $\mathrm{Fe}^{2+}$ and $\mathrm{Fe}^{3+}$ to $\mathrm{Fe}(\mathrm{OH})$ n-type structures at basic medium [47] and during EF treatment, iron species form the stable complexes with $\mathrm{H}_{2} \mathrm{O}_{2}$ at acidic medium, leading to the deactivation of catalysts [48]. Both EC and EF experiments were completed according to the CCD predicted sets as given in Table 2. For EC, the removal efficiencies of $\mathrm{p}-\mathrm{TA}$ and COD reduce beyond the optimum $\mathrm{pH}$ (8.11) as shown in Fig. 3a, c. Hydroxides of metal ions were found in dissolved form at low $\mathrm{pH}$, and concentration of metal hydroxides increase by enhancement of $\mathrm{pH}$. Removal efficiencies decrease due to the weak interaction among metal hydroxide ions and suspension impurities at high $\mathrm{pH}$ [49]. For EF, the removal of $\mathrm{p}$-TA and COD are higher in acidic conditions (Fig. 4a, c). This is due to the formation of metal hydroxide flocs and hydroxide radicals $(\mathrm{OH})$ for the neutralization of pollutant ions. At low $\mathrm{pH}$, the rate of generation of $\mathrm{Fe}^{2+}$ and $\mathrm{H}_{2} \mathrm{O}_{2}$ are high and, consequently, the formation of ${ }^{\circ} \mathrm{OH}$ also increases [50, 51]. In electro-Fenton process, a fixed amount of $\mathrm{H}_{2} \mathrm{O}_{2}(300-500 \mathrm{mg} / \mathrm{L})$ was fed to the reactor, which
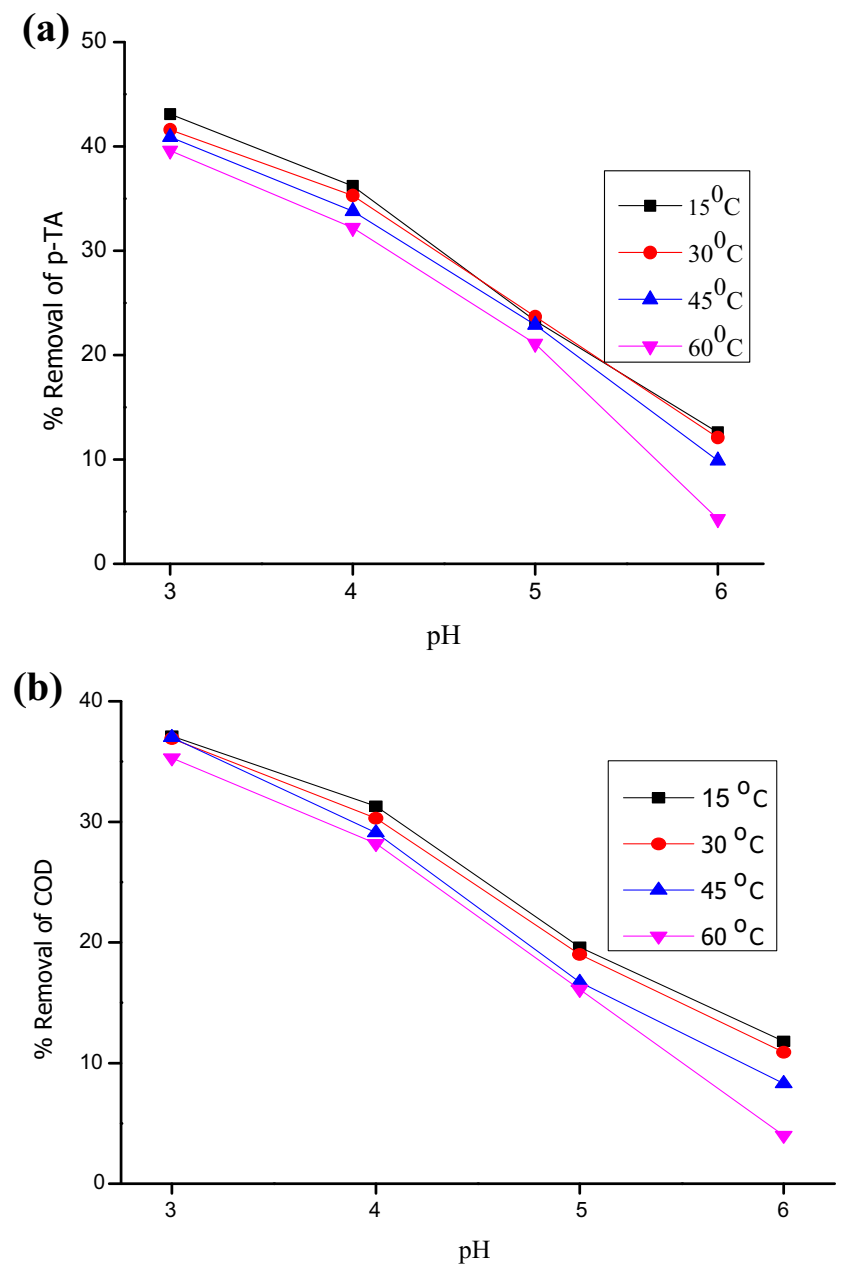

Fig. 2 Effect of $\mathrm{pH}$ at different temperatures in acid precipitation process $\mathbf{a}$ on removal of $\mathrm{p}-\mathrm{TA}$ and $\mathbf{b}$ on removal of COD 


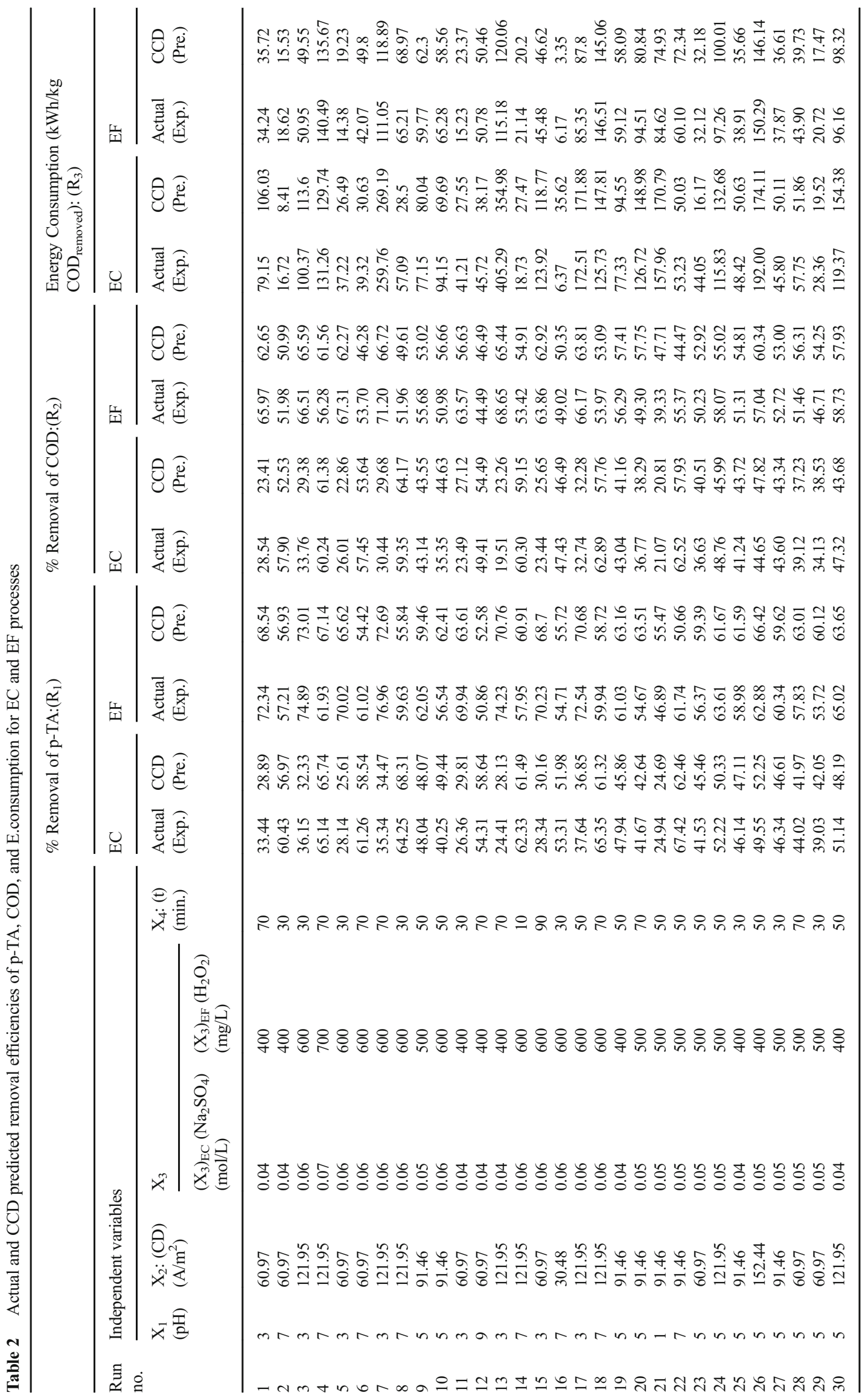


Fig. 3 Effect of $\mathrm{pH}, \mathrm{CD}$, time, and electrolyte concentration on percent removal of p-TA, COD, and E.consumption for EC

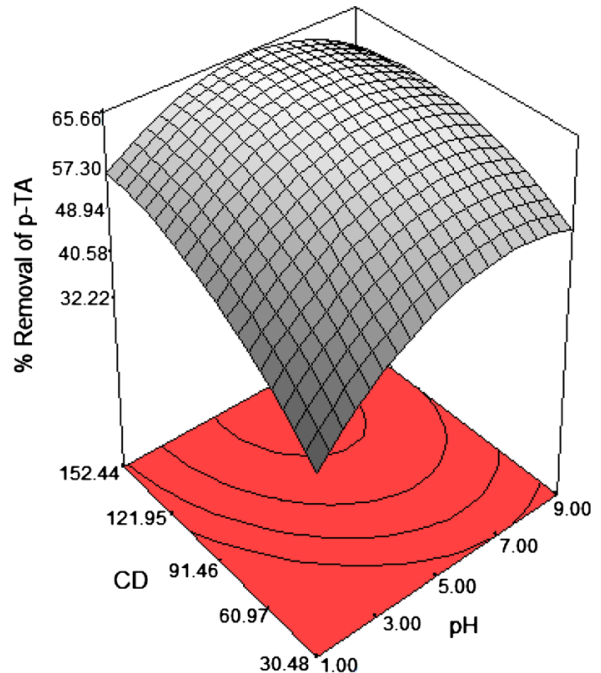

(a)

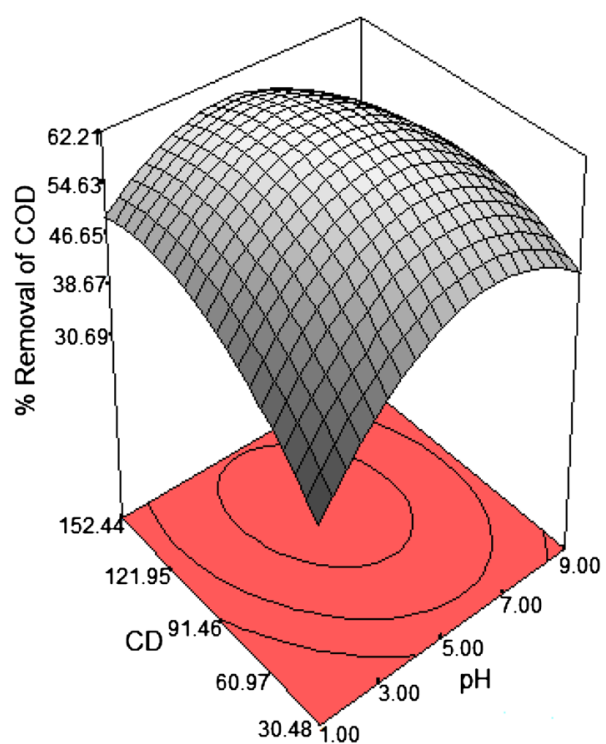

(c)

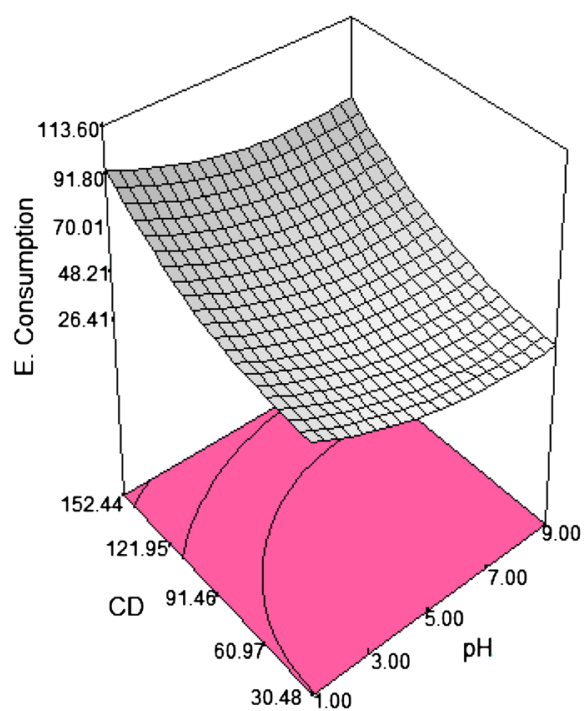

(e)

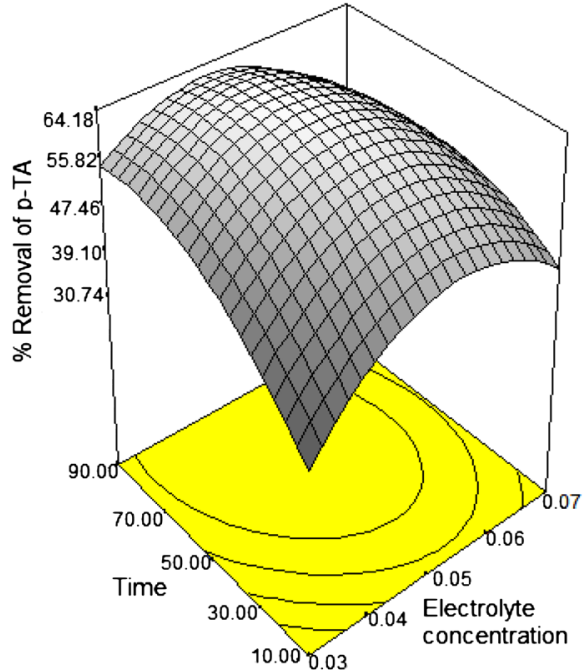

(b)

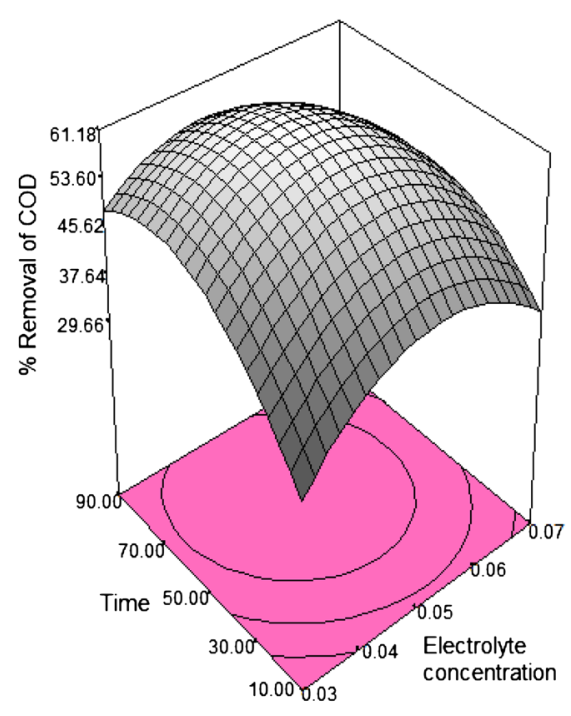

(d)

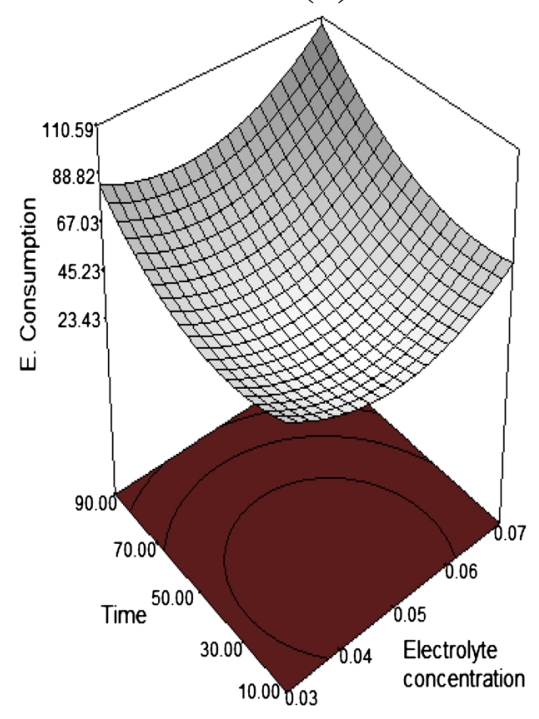

(f) 


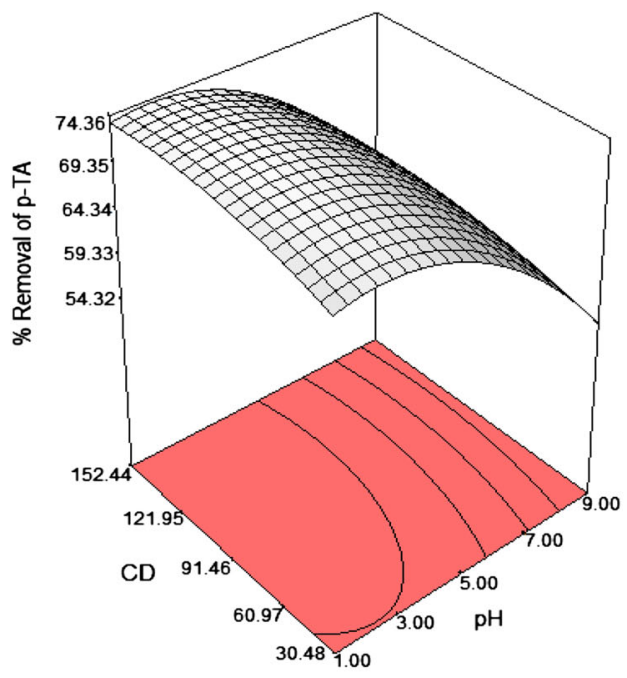

(a)

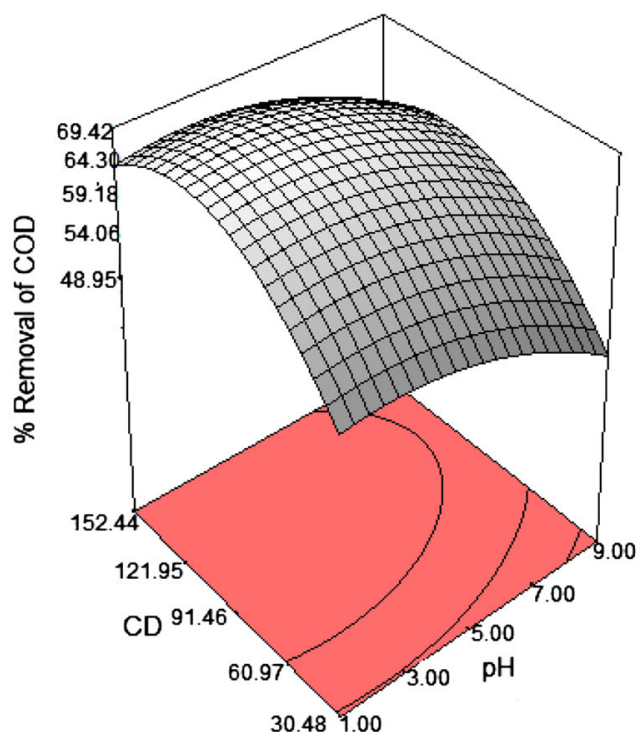

(c)

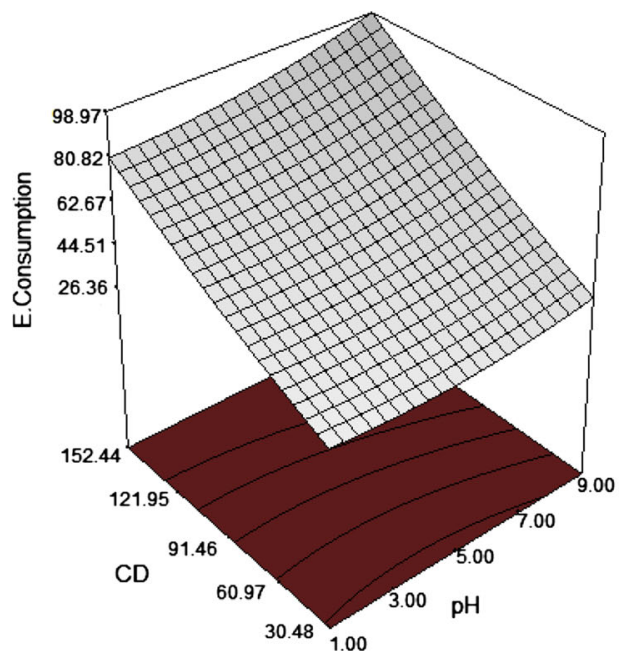

(e)

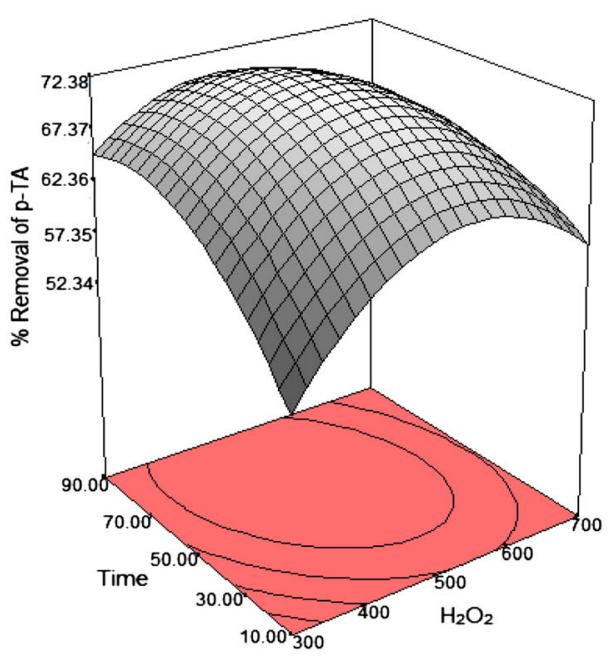

(b)

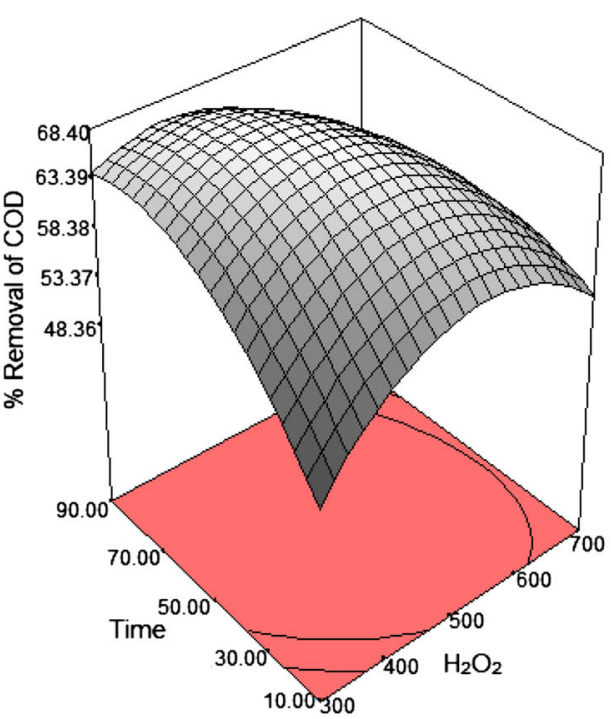

(d)

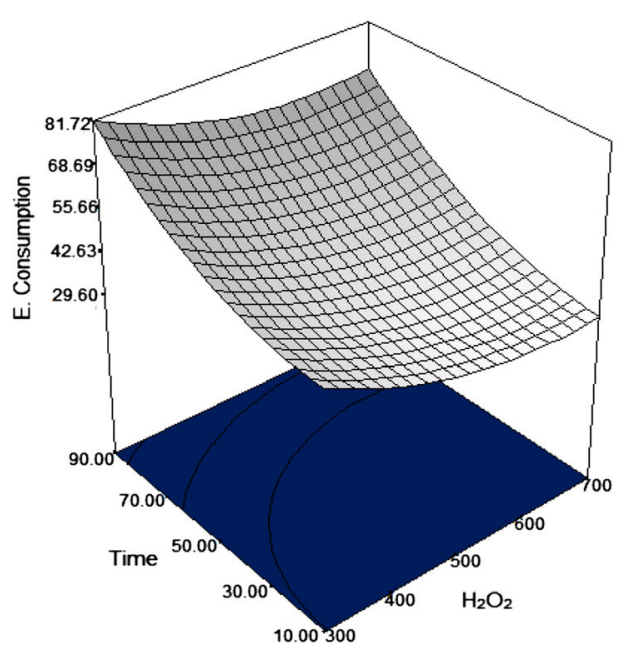

(f)

Fig. 4 Effect of $\mathrm{pH}, \mathrm{CD}$, time, and $\mathrm{H}_{2} \mathrm{O}_{2}$ concentration on percent removal of p-TA, COD, and E.consumption for EF 
enhances the formation of hydroxyl radical and increases the removal efficiencies. The generation of oxonium ions $\left(\mathrm{H}_{3} \mathrm{O}_{2}{ }^{+}\right)$ occur at very low $\mathrm{pH}$ [52], and high $\mathrm{pH}$ is responsible for the decomposition of $\mathrm{H}_{2} \mathrm{O}_{2}$ into water and oxygen. As $\mathrm{pH}$ influences the COD removal efficiency, energy consumption depends on COD. Hence, energy consumption is low at higher COD removal. E.consumption reaches optimum at $\mathrm{pH} 8.11$ for EC and 3.01 for EF as shown in Figs. $3 \mathrm{e}$ and $4 \mathrm{e}$ respectively.

\section{Effect of Current Density and Electrolysis Time on Percent Removal of P-TA, COD, and E.Consumption}

Current density and electrolysis time are very important operating parameters in electrochemical processes. Current densities of $30.48,60.97,91.46,121.95$, and $152.44 \mathrm{~A} / \mathrm{m}^{2}$ with different slots of time, 10, 30, 50, 70, and $90 \mathrm{~min}$, were studied during both the processes. Amount of charges generated during electrochemical reactions increases with current density which results in higher removal of p-TA and COD. Similarly, metal ion concentration and hydroxide radicals increase with electrolysis time. The conductivity of electrolytic solution increases with time due to that the rapid movement of ions and radicals results in higher efficiency. Beyond optimum values (50.42 min for EC and $42.63 \mathrm{~min}$ for $\mathrm{EF}$ ), percent removal decreases due to low generation of metal ions and $\mathrm{OH}$ radicals. The results are shown in Figs. $4 \mathrm{a}-\mathrm{d}$ and $5 \mathrm{a}-\mathrm{d}$. It was found that, beyond the optimum current density of $103.39 \mathrm{~A} / \mathrm{m}^{2}$ for EC and $88.90 \mathrm{~A} / \mathrm{m}^{2}$ for EF processes, removal efficiencies decrease due to the consumption of considerable amount of charge during electrolysis by some side reactions, and, ultimately, the corrosion of electrodes enhances as discussed below.

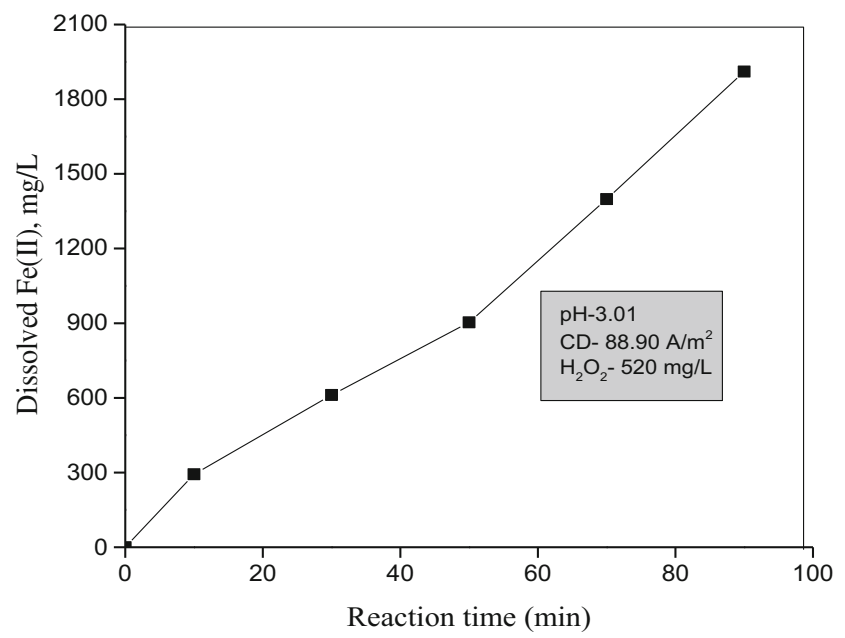

Fig. 5 Concentration of ferrous ion $\left(\mathrm{Fe}^{2+}\right)$ in solution with reaction time at optimum conditions 

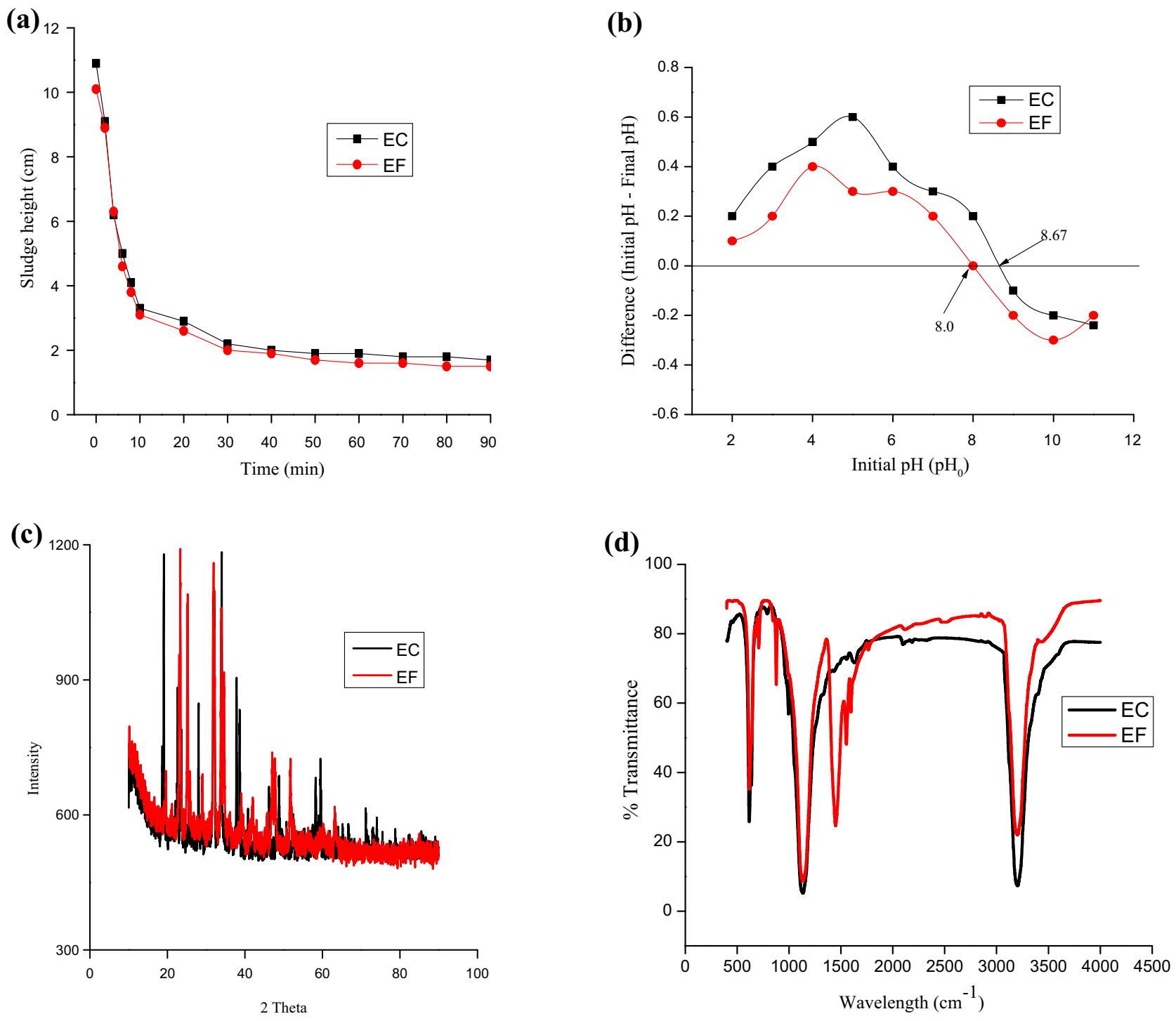

(e)

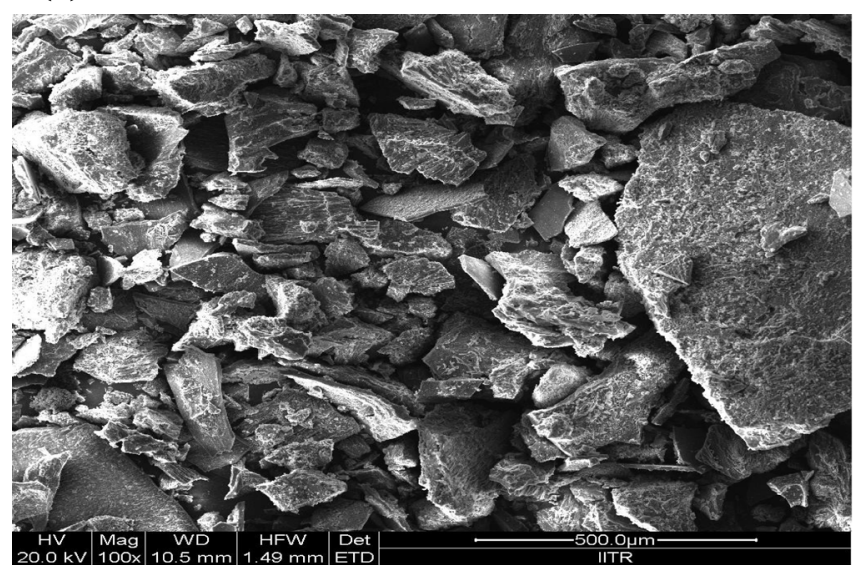

(f)

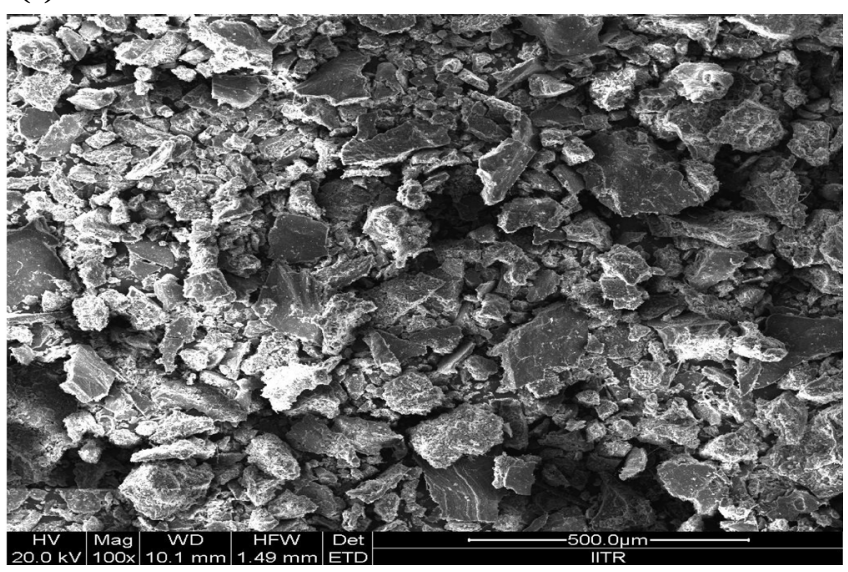

Fig. 6 a Settling characteristics. b Point of zero charge. $\mathbf{c}$ XRD spectra. d FTIR spectra. e, f SEM images. g, h DTA/TGA graphs obtained by the ECand EF-generated sludge, respectively 
- Self decomposition of $\mathrm{H}_{2} \mathrm{O}_{2}$ [53]:

$$
2 \mathrm{H}_{2} \mathrm{O}_{2} \rightarrow 2 \mathrm{H}_{2} \mathrm{O}+\mathrm{O}_{2}
$$

- Removal of metals from solution due to metal precipitation on the cathode surface [54].

In addition, higher current density results in temperature rise of electrolytic solution and higher energy consumption $[55,56]$. E.consumption strongly depends on current density and electrolysis time. Beyond optimum conditions, removal decreases; therefore, the energy consumption increases. The results are shown in Figs. 3e, f and 4e, f.

\section{Effect of Electrolyte and $\mathrm{H}_{2} \mathrm{O}_{2}$ Concentration on Percent Removal of P-TA, COD, and E.Consumption}

Electrolyte is an important part in electrochemical treatment for the enhancement of solution conductivity and electron transfer rate in electrolysis. Different concentrations of an electrolyte (sodium sulfate) were used in EC process and obtained the optimum value $(0.05 \mathrm{M})$ as shown in Figs 4b, d. This optimum electrolyte concentration $(0.05 \mathrm{M})$ was also used in electro-Fenton process. The optimum $\mathrm{H}_{2} \mathrm{O}_{2}$ concentration is highly important to get maximum removal efficiency in EF process. In the present study, iron anode was used for EC and EF processes, which increases $\mathrm{Fe}^{2+}$ ion concentration during electrolysis. Formation of $\mathrm{OH}$ radicals are catalyzed through anodic iron in the EF process as can be seen in Eqs. (3) to (6). Depending on wastewater COD (after acid

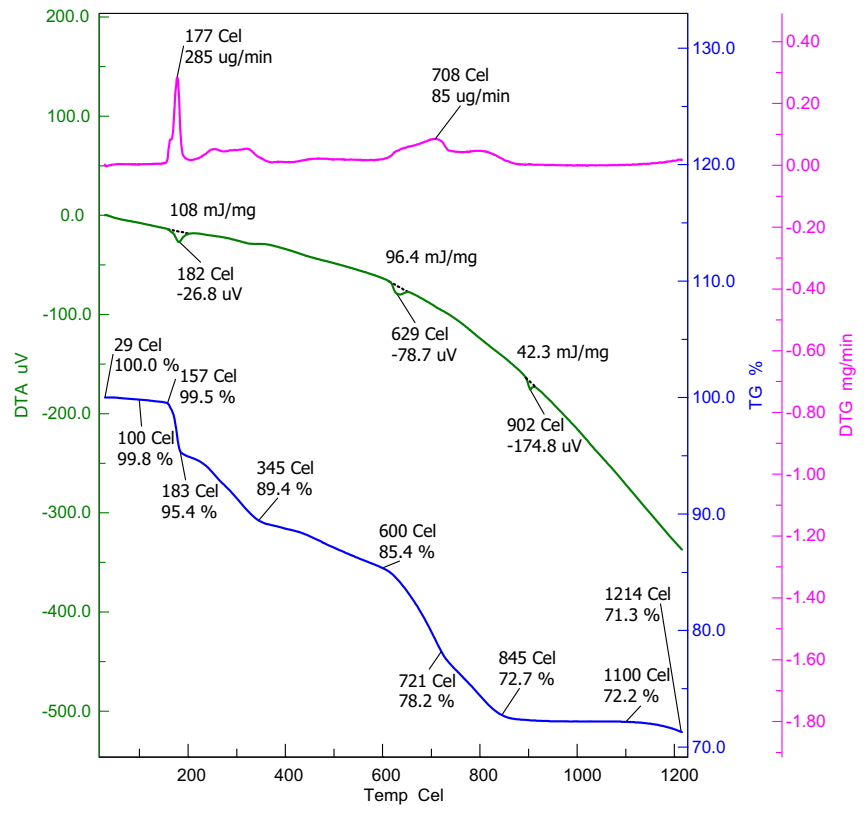

(g) precipitation), i.e., $661 \mathrm{mg} / \mathrm{L}$, theoretical amount of $\mathrm{H}_{2} \mathrm{O}_{2}$ required to provide entire $\mathrm{O}_{2}$ for oxidation was calculated by $(34 / 16) \times 661=1404.63 \mathrm{mg} / \mathrm{L}$. The $\mathrm{H}_{2} \mathrm{O}_{2}$ was used in concentration range $300-700 \mathrm{mg} / \mathrm{L}$ during treatment and achieved the optimal value $(522 \mathrm{mg} / \mathrm{L})$ as shown in Fig. $3 b$, d. It was found that beyond optimum $\mathrm{H}_{2} \mathrm{O}_{2}$ concentration, efficiencies decreased due to the presence of excess amount of hydrogen peroxide leading to the scavenging effect on hydroxyl radicals [39, 40]:

$\mathrm{H}_{2} \mathrm{O}_{2}+{ }^{\cdot} \mathrm{OH} \rightarrow \mathrm{HO}_{2}{ }^{\cdot}+\mathrm{H}_{2} \mathrm{O}$

E.consumption decreases with increase in electrolyte concentration up to $0.05 \mathrm{M}$ as shown in Fig. 3f, and beyond this optimal value, it starts to increase in the EC process. During EF treatment, E.consumption decreases with $\mathrm{H}_{2} \mathrm{O}_{2}$ concentration up to optimum value and after that, it increases as shown in Fig. 4g.

\section{Effect of Ferrous Ion $\left(\mathrm{Fe}^{2+}\right)$ Concentration in EF Process}

$\mathrm{Fe}^{2+}$ ion concentrations play a vital role in the EF process. The concentration of $\mathrm{Fe}^{2+}$ ions accelerates the formation of hydroxyl radicals (main oxidizing agent) in the electrolytic solution resulting in higher removal efficiency [57]. In the presence of $\mathrm{H}_{2} \mathrm{O}_{2}, \mathrm{Fe}^{2+}$ ions convert to ferric ions $\left(\mathrm{Fe}^{3+}\right)$. The coagulating nature of $\mathrm{Fe}^{3+}$ enhances the sludge generation with $\mathrm{Fe}(\mathrm{OH})_{3}[58]$. However, the excess amount of $\mathrm{Fe}^{2+}$ ions causes consumption of ${ }^{\bullet} \mathrm{OH}$ and affects the removal [59].

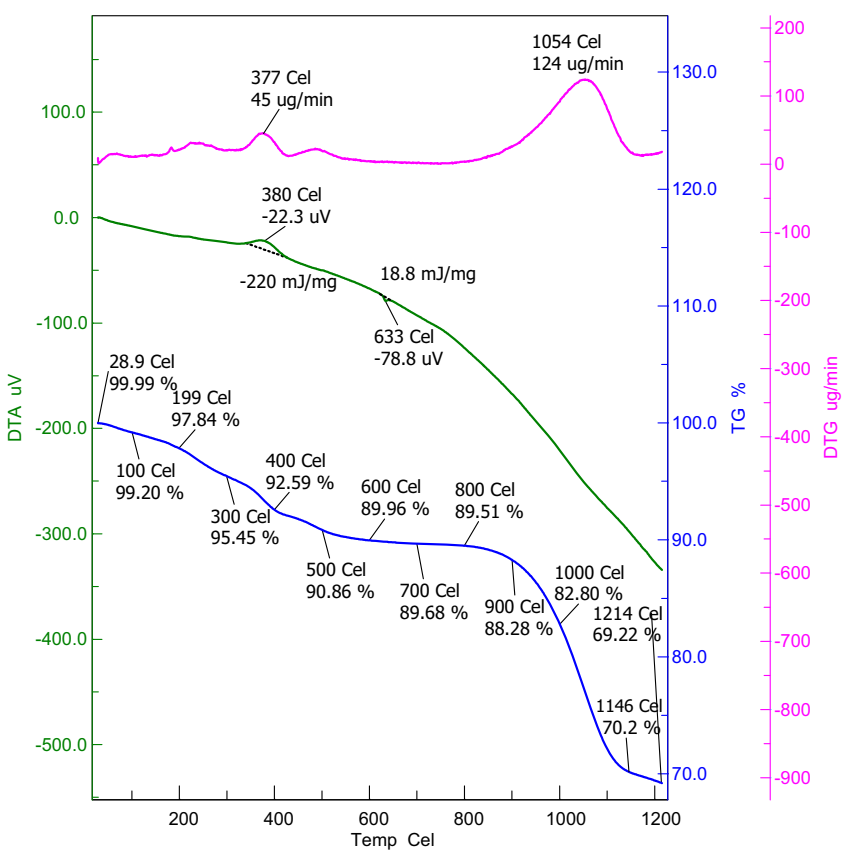

(h)

Fig. 6 (continued) 
Table 4 Elemental composition of sludge based on EDAX results for the EC and EF processes

\begin{tabular}{lllllll}
\hline Element & & C K & O K & Na K & S K & Fe K \\
\hline Weight \% & EC (sludge) & 11.21 & 30.44 & 21.62 & 7.09 & 29.64 \\
& EF (sludge) & 14.58 & 26.34 & 19.64 & 12.53 & 26.91 \\
\hline
\end{tabular}

Concentration of dissolved $\mathrm{Fe}^{2+}$ ions during the EF process with electrolysis time at optimum operating conditions is shown in Fig. 5.

\section{RSM Study}

\section{Optimization}

Both electrochemical processes were optimized to achieve maximum removal of $\mathrm{p}$-TA and COD with minimum E.consumption based on CCD results. All the operating conditions with their experimental run data are given in Table 2 . The optimum results of CCD predicted and experimental test runs were obtained at optimum operating conditions as shown in Table 3. Proximity of CCD predicted values and experimental run results indicate good competence of model.

\section{Model Equations for Responses Based on ANOVA Result}

Second-order polynomial equations have been used for both electrochemical processes to express regression model in terms of independent variables.

Generalized equation:

$$
\begin{aligned}
\mathrm{Ri} & =\mathrm{b}_{0}+\mathrm{b}_{1} \times \mathrm{pH}+\mathrm{b}_{2} \times \mathrm{CD}+\mathrm{b}_{3} \times \mathrm{C}_{\mathrm{i}}+\mathrm{b}_{4} \times \mathrm{t}+\mathrm{b}_{11} \times \mathrm{pH}^{2} \\
& +\mathrm{b}_{22} \times \mathrm{CD}^{2}+\mathrm{b}_{33} \times \mathrm{C}_{\mathrm{i}}^{2}+\mathrm{b}_{44} \times \mathrm{t}^{2}+\mathrm{b}_{12} \times \mathrm{pH} \times \mathrm{CD}+\mathrm{b}_{13} \\
& \times \mathrm{pH} \times \mathrm{C}_{\mathrm{i}}+\mathrm{b}_{14} \times \mathrm{pH} \times \mathrm{t}+\mathrm{b}_{23} \times \mathrm{CD} \times \mathrm{C}_{\mathrm{i}}+\mathrm{b}_{24} \times \mathrm{CD} \times \mathrm{t} \\
& +\mathrm{b}_{34} \times \mathrm{C}_{\mathrm{i}} \times \mathrm{t}
\end{aligned}
$$

Responses $\left(R_{1}, R_{2}\right.$, and $\left.R 3\right)$ are given below:

$$
\begin{aligned}
\mathrm{p}-\mathrm{TA} & \\
\mathrm{R}_{1}{ }^{\mathrm{EC}} & =49.9+4.3 \times \mathrm{pH}+2.16 \times \mathrm{j}+2.37 \times \mathrm{C}_{1}-6.62 \times \mathrm{t}+0.90 \\
& \times \mathrm{pH}^{2}-0.39 \times \mathrm{j}^{2}-0.41 \times \mathrm{C}_{1}^{2}-3.44 \times \mathrm{t}^{2}+1.4 \times \mathrm{pH} \times \mathrm{j} \\
& +1.25 \times \mathrm{pH} \times \mathrm{C}_{1}-2.29 \times \mathrm{pH} \times \mathrm{t}-0.10 \times \mathrm{j} \times \mathrm{C}_{1}-2.9 \times \mathrm{j} \times \mathrm{t} \\
& +2.71 \times \mathrm{C}_{1} \times \mathrm{t} \\
\mathrm{R}_{1}{ }^{\mathrm{EF}} & =66.00-5.51 \times \mathrm{pH}+4.30 \times \mathrm{j}-4.93 \times \mathrm{C}_{2}+5.56 \times \mathrm{t}-3.57 \\
& \times \mathrm{pH}^{2}+2.54 \times \mathrm{j}^{2}+3.39 \times \mathrm{C}_{2}^{2}+2.2 \times \mathrm{t}^{2}-1.89 \times \mathrm{pH} \\
& \left.\times \mathrm{j}-1.35 \times \mathrm{pH} \times \mathrm{C}_{2}-0.80 \times \mathrm{pH} \times \mathrm{t}+2.67 \times \mathrm{j} \times \mathrm{C}_{2}+0.73\right) \\
& \times \mathrm{j} \times \mathrm{t}-1.80 \times \mathrm{C}_{2} \times \mathrm{t}
\end{aligned}
$$

\section{COD}

$$
\begin{aligned}
\mathrm{R}_{2}{ }^{\mathrm{EC}} & =45.52+4.7 \times \mathrm{pH}+2.08 \times \mathrm{j}+2.3 \times \mathrm{C}_{1}-6.54 \times \mathrm{t} \\
& +1 \times \mathrm{pH}^{2}-0.69 \times \mathrm{j}^{2}-0.66 \times \mathrm{C}_{1}{ }^{2}-2.74 \times \mathrm{t}^{2}+1.74(14) \\
& \times \mathrm{pH} \times \mathrm{j}+1.18 \times \mathrm{pH} \times \mathrm{C}_{1}-1.68 \times \mathrm{pH} \times \mathrm{t}-0.12 \times \mathrm{j} \\
& \times \mathrm{C}_{1}-2.6 \times \mathrm{j} \times \mathrm{t}+2.76 \times \mathrm{C}_{1} \times \mathrm{t} \\
\mathrm{R}_{2}{ }^{\mathrm{EF}}= & 60.79-3.29 \times \mathrm{pH}+4.12 \times \mathrm{j}-6.82 \times \mathrm{C}_{2}+8.15 \\
& \times \mathrm{t}-3.74 \times \mathrm{pH}^{2}+2.13 \times \mathrm{j}^{2}+4.01 \times \mathrm{C}_{2}{ }^{2}+2.4 \times \mathrm{t}^{2}-0.72 \\
& \times \mathrm{pH} \times \mathrm{j}-2.11 \times \mathrm{pH} \times \mathrm{C}_{2}+0.6 \times \mathrm{pH} \times \mathrm{t}+2.23 \times \mathrm{j} \times \mathrm{C}_{2} \\
& +2.03 \times \mathrm{j} \times \mathrm{t}-2.57 \times \mathrm{C}_{2} \times \mathrm{t}
\end{aligned}
$$

E.consumption

$$
\begin{aligned}
\mathrm{R}_{3}{ }^{\mathrm{EC}} & =180.8-6.10 \times \mathrm{pH}+74.62 \times \mathrm{j}-26.71 \times \mathrm{C}_{1}+109.1 \\
& \times \mathrm{t}+5.12 \times \mathrm{pH}^{2}-12.6 \times \mathrm{j}^{2}+2.09 \times \mathrm{C}_{1}{ }^{2}+19.5 \times \mathrm{t}^{2}-38.6 \\
& \times \mathrm{pH} \times \mathrm{j}+9.28 \times \mathrm{pH} \times \mathrm{C}_{1}-9.09 \times \mathrm{pH} \times \mathrm{t}-10.78 \times \mathrm{j} \times \mathrm{C}_{1} \\
& +49.9 \times \mathrm{j} \times \mathrm{t}-14 \times \mathrm{C}_{1} \times \mathrm{t} \\
\mathrm{R}_{3}{ }^{\mathrm{EF}} & =129.9+11 \times \mathrm{pH}+75.8 \times \mathrm{j}+5.23 \times \mathrm{C}_{2}+33.5 \times \mathrm{t} \\
& +5.45 \times \mathrm{pH}^{2}+8.5 \times \mathrm{j}^{2}-3.9 \times \mathrm{C}_{2}{ }^{2}+3.58 \times \mathrm{t}^{2}+7.88 \\
& \times \mathrm{pH} \times \mathrm{j}+1.56 \times \mathrm{pH} \times \mathrm{C}_{2}+1.69 \times \mathrm{pH} \times \mathrm{t}-3.78 \mathrm{j} \times \mathrm{C}_{2} \\
& +16.5 \times \mathrm{j} \times \mathrm{t}+3.26 \times \mathrm{C}_{2} \times \mathrm{t}
\end{aligned}
$$

where $\mathrm{CD}$ is current density, $\mathrm{C}_{1}$ is electrolyte concentration, $\mathrm{C}_{2}$ is $\mathrm{H}_{2} \mathrm{O}_{2}$ concentration, and $\mathrm{t}$ is time.

\section{Sludge Analysis}

\section{Settling, PZC, and XRD}

Settling-Figure 6a indicates the settling characteristics of sludge generated by the EC and EF processes at optimum operating condition. Initially $(t=0)$, the position of the sludge interface was 10.9 and $10.1 \mathrm{~cm}$ for EC and EF, respectively, and after $30 \mathrm{~min}$, the level $(2.2 \mathrm{~cm})$ of the EC-generated sludge was higher than the level of $(2 \mathrm{~cm})$ of the EFgenerated sludge. The settling levels of EC- and EFgenerated sludge were constant at 1.8 and $1.5 \mathrm{~cm}$, respectively, after $70 \mathrm{~min}$. The results show that the settling level of the EF-generated sludge was faster than that of the EC-generated sludge.

Point of zero charge (PZC) - It is basically a $\mathrm{pH}$ value at which a solid submerged in the electrolyte shows zero net charge at solid surface [60]. The salt addition method proposed by the American Society for Testing of Materials D3838-05 was used to determine the PZC in this study [61]. Cross-over point on resulting curve plotted between $\Delta \mathrm{pH}$ $\left(\Delta \mathrm{pH}=\mathrm{pH}_{0}(\right.$ initial $\mathrm{pH})-\mathrm{pH}_{\mathrm{f}}($ final $\left.\mathrm{pH})\right)$ and initial $\mathrm{pH}$ $\left(\mathrm{pH}_{0}\right)$ at $\Delta \mathrm{pH}=0$ gives the $\mathrm{PZC}$ value. The $\mathrm{PZC}$ values for EC- and EF-generated sludges are 8.67 and 8.0, respectively, as shown in Fig. 6 b. 
XRD - The XRD spectrum gives an idea about morphological structures and extent of crystallinity of the sample. The spectra of the sludge generated (dried at ambient temperature) by the EC and EF processes are shown in the Fig. 6c. The XRD spectra of both the EC- and EFgenerated sludges show broad and shallow diffraction peaks. Broad and lower intensity peaks of Bragg reflection shows that the analyzed phase occupies an order of short range that is poorly crystalline. The XRD spectra of both the EC- and EF-generated sludges show some sharp peak which indicates the amorphous nature of the sludge.

\section{FTIR, SEM/EDX, and DTA/TGA}

FTIR-FTIR spectroscopy is used to determine the information about surface chemistry as well as the functional groups present in the sample. Functional groups in the sludge sample show electrolyte interaction between cations and flocs, resulting in colloid removal during treatment. The spectra of the EC-and EF-generated sludges are shown in Fig. 6d. Here, the broad and intense bands of 3203 and $3213 \mathrm{~cm}^{-1}$ attributed to the stretching vibrations of the hydroxyl group and characteristics of hydrogen ring. Wavelengths of 1134 and $1448 \mathrm{~cm}^{-1}$ show the presence of a carbonyl group in the sludge sample. Peaks are observed in the range from 1600 to $400 \mathrm{~cm}^{-1}$, which depicted aromatic $\mathrm{C}=\mathrm{C}$ stretching.

SEM/EDX - SEM analysis gives an idea about surface structure, i.e., whether it is crystalline or amorphous. EDX predicts the composition of the elements (weight \%) in the sample. SEM images of the sludges generated (dried at ambient temperature) after EC and EF treatments are shown in Fig. 6e, f. It is found that the EF-generated sludge has high porosity as compared to the EC-generated sludge. Hence, the particle size of the EF-generated sludge stays more downcast than that of the EC-generated sludge. Elemental composition (in weight \%) for EF- and EC-generated sludges through EDX analysis is given in Table 4.

DTA/TGA — Figure $6 \mathrm{~g}$, $\mathrm{h}$ shows the DTA/TGA analysis of the EC- and EF-generated sludges, respectively. The analyses were performed in dynamic air atmosphere with $200 \mathrm{~mL} / \mathrm{min}$ air flow rate and at $10 \mathrm{~K} / \mathrm{min}$ heating rate by using calcined $\mathrm{Al}_{2} \mathrm{O}_{3}$ as a reference material. TGA indicates that percent weight loss of the EC-generated sludge was more than that of EF due to the formation of $\mathrm{CO}_{2}$ and $\mathrm{CO}$. Oxidation of the EC-generated sludge exhibits endothermic reactions at temperatures 182,629 , and $902{ }^{\circ} \mathrm{C}$ with $108,96.4$, and $42.3 \mathrm{~mJ} /$ $\mathrm{mg}$ heat requirements, respectively. The EF-generated sludge shows an exothermic nature at $400{ }^{\circ} \mathrm{C}$ with $220 \mathrm{~mJ} / \mathrm{mg}$ and an endothermic behavior at $650{ }^{\circ} \mathrm{C}$ with $18.8 \mathrm{~mJ} / \mathrm{mg}$ heat requirements. DTG spectrum of the EC-generated sludge shows maximum of $0.285 \mathrm{mg} / \mathrm{min}$ rate of weight loss at $177^{\circ} \mathrm{C}$ and minimum of $0.085 \mathrm{mg} / \mathrm{min}$ at $708^{\circ} \mathrm{C}$ where the combustion of volatiles takes place exothermally. DTG spectrum of the EF- generated sludge shows maximum rate of weight loss of $0.124 \mathrm{mg} / \mathrm{min}$ at $1054{ }^{\circ} \mathrm{C}$ and minimum of $0.045 \mathrm{mg} / \mathrm{min}$ at $377{ }^{\circ} \mathrm{C}$ temperatures. TGA graphs of the EC- and EFgenerated sludges show that about 0.2 and $0.8 \%$ weight were reduced below $100^{\circ} \mathrm{C}$, respectively. This is due to the fact that a small amount of water was not evaporated during drying at ambient temperature.

\section{Conclusion}

In this study, acid precipitation of wastewater was done at different $\mathrm{pH}$ levels and temperatures, and the effects of various operational parameters on $\mathrm{EC}$ and $\mathrm{EF}$ treatment methods were evaluated based on removal of p-TA and COD with E.consumption. Approximately $43 \%$ of p-TA and $37 \%$ of COD from aqueous solution were removed by acid precipitation. The filtered supernatant was further treated by electrochemical processes and obtained maximum removal of $\mathrm{p}-\mathrm{TA}$ $64.83 \%$, COD $61.27 \%$ with E.consumption $(\mathrm{kWh} /$ $\left.\mathrm{kgCOD}_{\text {removed }}\right) 69.71$ at $\mathrm{pH} 8.1, \mathrm{CD} 103.39 \mathrm{~A} / \mathrm{m}^{2}, \mathrm{Na}_{2} \mathrm{SO}_{4}$ concentration $0.05 \mathrm{~mol} / \mathrm{L}$, and time $50.42 \mathrm{~min}$ by EC process and of p-TA $74.50 \%$, COD $68.21 \%$ with E.consumption $\left(\mathrm{kWh} / \mathrm{kgCOD}{ }_{\text {removed }}\right) 41.60$ at $\mathrm{pH} 3.01, \mathrm{CD} 88.90 \mathrm{~A} / \mathrm{m}^{2}$, $\mathrm{H}_{2} \mathrm{O}_{2}$ concentration $522 \mathrm{mg} / \mathrm{L}$, and time $58.86 \mathrm{~min}$ by EF process. The amount of sludge generated through $\mathrm{EC}$ process was more than that through EF process. High proximity of CCD predicted values and test run results shows good adequacy of model in this study. Hence, in the present study, the EF process was found to be more efficient than the EC process based on percent removal and energy consumption.

Acknowledgements Thte authors are thankful to the Department of Chemical Engineering, Indian Institute of Technology, Roorkee, for providing the necessary technical facilities and the Ministry of Human Resource Development (New Delhi, India) for the financial support.

\section{References}

1. Wittcoff HA, Reuben BG, Plotkin JS (2004) Industrial organic chemicals, 2nd edn. Wiley, Hoboken, NJ

2. Kleerebezem R, Hulshoff Pol LW, Lettinga G (2005) High rate treatment of terephthalic acid production wastewater in a twostage anaerobic bioreactor. Biotechnol Bioeng 91:169-179

3. Karthik M, Dafale N, Pathe P, Nandy T (2008) Biodegradability enhancement of purified terephthalic acid wastewater by coagulation-flocculation process as pretreatment. J Hazard Mater 154:721-730

4. Guyot JP, Macarie H, Noyola A (1990) Anaerobic digestion of a petrochemical wastewater using the UASB process. Appl Biochem Biotechnol 24(25):579-589

5. Macarie H, Guyot JP (1992) Inhibition of the methanogenic fermentation of p-toluic acid (4-methylbenzoic acid) by acetate. Appl Microbiol Biotechnol 38:398-402 
6. Young JC, Kim IS, Page IC, Wilson DR, Brown GJ, Cocci AA (2000) Two-stage anaerobic treatment of purified terephthalic acid production wastewaters. Water Sci Technol 42:277-282

7. Noyola A, Macarie W, Guyot JP (2006) Treatment of terephthalic acid plant wastewater with an anaerobic fixed film reactor. Environ Technol 11:239-248

8. Zhang XX, Cheng SP, Wan YQ, Sun SL, Zhu CJ, Zhao DY, Pan WY (2006) Degradability of five aromatic compounds in a pilot wastewater treatment system. Inter Biodeter Biodegr 58:94-98

9. Matsumoto M, Hirata-Koizumi M, Ema M (2008) Potential adverse effects of phthalic acid esters on human health: a review of recent studies on reproduction. Regul Toxicol Pharmacol 50:37-49

10. Manzurola E, Apelblat A (2002) Solubilities of L-glutamic acid, 3nitrobenzoic acid, p-toluic acid, calcium-L-lactate, calcium gluconate, magnesium-DL-aspartate, and magnesium-L-lactate in water. J Chem Thermodyn 34(7):1127-1136

11. Anand MV, Srivastava VC, Singh S, Bhatnagar R, Mall ID (2014) Electrochemical treatment of alkali decrement wastewater containing terephthalic acid using iron electrodes. J Taiwan Ins Chem Eng 45:908-913

12. Saxena MP, Gupta AK, Sharma SK, Bangwal SD, Kumar K (2013) A process for the preparation of $\mathrm{p}$-toluic acid by liquid phase oxidation of p-xylene in water, CA patent $2603160 \mathrm{C}$

13. Wu CH (2004) Comparison of azo dye degradation efficiency using $\mathrm{UV} /$ single semiconductor and UV/coupled semiconductor systems. Chemosphere 57(7):601-608

14. Shirota M, Seki T, Tago K, Katoh H, Marumo H, Furuya M, Shindo T, Ono H (2008) Screening of toxicological properties of 4methylbenzoic acid by oral administration to rats. J Toxicol Sci 33:431-445

15. Wu CH (2007) Photodegradation of toluic acid isomers by UV/ $\mathrm{TiO}_{2}$. React Kinet Catal Lett 90(2):301-308

16. US EPA (1992) Code of Federal Regulations 40 CFR. Part 136

17. Proposed Effluent and Emission Standards for Petroleum Oil Refineries, Central Pollution Control Board. 2005 (http://www. cpcb.nic.in/finalstandardsoilrefineries271205.doc) as accessed on 03.02.09.

18. Anbia M, Salehi S (2012) Synthesis of polyelectrolyte-modified ordered nonporous carbon for removal of aromatic organic acids from purified terephthalic acid wastewater. Chem Eng Res Des 90(7):975-983

19. Chen J (2006) Preparation of highly efficient PTA degradation bacteria and biological treatment of PTA wastewater. Environ Sci Technol 10:75-76

20. Chen CY, Chen CC, Chung YC (2007) Removal of phthalate esters by R-cyclodextrin linked chitosan bead. Bioresour Technol 98: 2578-2583

21. Verma S, Prasad B, Mishra IM (2014) Adsorption kinetics and thermodynamics of COD removal of acid pre-treated petrochemical wastewater by using granular activated carbon. Sep Sci Technol 49(7):1067-1075

22. Garg KK, Prasad B, Srivastava VC (2014) Comparative study of industrial and laboratory prepared purified terephthalic acid (PTA) wastewater with electrocoagulation process. Sep Purif Tech 128: $80-88$

23. Garg KK, Prasad B, Srivastava VC (2016) Development of Box Behnken design for treatment of terephthalic acid wastewater by electrocoagulation process: optimization of process and analysis of sludge. J Environ Chemical Eng 4:178-190

24. Verma S, Prasad B, Mishra IM (2010) Pretreatment of petrochemical wastewater by coagulation and flocculation and the sludge characteristics. J Hazard Mater 178(1-3):1055-1064. doi:10. 1016/j.jhazmat.2010.02.047. 20303661

25. Wen YZ, Tong SP, Zheng KF, Wang LL, Lv JZ, Lin J (2006) Removal of terephthalic acid in alkalized wastewater by ferric chloride. J Hazard Mater 138:169-172
26. Verma S, Prasad B, Mishra IM (2011) Thermochemical treatment (thermolysis) of petrochemical wastewater: COD removal mechanism and floc formation. Ind Eng Chem Res 50(9):5352-5359

27. Wu S, Cheng Z, Wang S, Shan X (2011) Recovery of terephthalic acid from alkali reduction wastewater by cooling crystallization. Chem Eng Technol 34:1614-1618

28. Park TJ, Lima JS, Lee YW, Kim SH (2003) Catalytic supercritical water oxidation of wastewater from terephthalic acid manufacturing process. J Supercrit Fluids 26:201-213

29. Thiruvenkatachari R, Tae OK, Jung CJ, Subramanian B, Manickam M, Shik M (2007) Application of several advanced oxidation processes for the destruction of terephthalic acid. J Hazard Mater 142(1):308-314

30. Mollah MYA, Schennach R, Parga JR, Cocke DL (2000) Electrocoagulation (EC) — science and applications. J Hazard Mater B84:29-41

31. Tagliabue M, Reverberi AP, Bagatin R (2014) Boron removal from water: needs, challenges and perspectives. J Clean Prod 77:56-64

32. Sayiner G, Kandemirli F, Dimoglo A (2008) Evaluation of boron removal by electrocoagulation using iron and aluminum electrodes. Desalination 230(1-3):205-212

33. Mohajeri S, Aziz HA, Isa MH, Zahed MA, Adlan MN (2009) Statistical optimization of process parameters for landfill leachate treatment using electro-Fenton technique. J Hazard Mater 176:749 758

34. Lee H, Shoda M (2008) Removal of COD and color from livestock wastewater by the Fenton method. J Hazard Mater 153:1314-1319

35. Mohanty NR, Wei IW (1993) Oxidation of 2, 4-dinitrotoluene using Fenton's reagent: reaction mechanisms and their practical applications. Hazard Waste Hazard Mater 10:171-183

36. Guinea E, Arias C, Cabot PL, Garrido JA, Rodriguez RM, Centella F, Brillas E (2008) Mineralization of salicylic acid in acidic aqueous medium by electrochemical advanced oxidation processes using platinum and boron-doped diamond as anode and cathodically generated hydrogen peroxide. Water Res 42:499-511

37. Virkutyte J, Rokhina E, Jegatheesan V (2010) Optimization of electro-Fenton denitrification of a model wastewater using a response surface methodology. Bioresour Technol 101:1440-1446

38. Macarie H, Noyola A, Guyot JP (1992) Anaerobic treatment of a petrochemical wastewater from a terephthalic acid plant. Water Sci Technol 25(7):223-235

39. Macarie H, Guyot J (1992) Inhibition of the methanogenic fermentation of p-toluic acid (4-methylbenzoic acid) by acetate. Appl Microbiol Biotechnol 38(3):398-402. doi:10.1007/BF00170093

40. APHA (American Public Health Association), AWWA (American Water Works Association), WPCF (Water Pollution Control Federation) (1995) Standard methods for the examination of water and wastewater. APHA, Washington DC, USA

41. Garg KK, Prasad B (2015) Electrochemical treatment of benzoic acid (BA) from aqueous solution and optimization of parameters by response surface methodology (RSM). J Taiwan Inst Chem Eng 56: $122-130$

42. Thiruvenkatachari R, Kwon TO, Moon IS (2006) Degradation of phthalic acids and benzoic acid from terephthalic acid wastewater by advanced oxidation processes. J Environ Sci Health Part-A Tox/ Hazard Subst Environ Eng 41(8):1685-1697. doi:10.1080/ 10934520600754136.16835120

43. Verma S, Prasad B, Mishra IM (2014) Treatment of petrochemical wastewater by acid precipitation and carbon adsorption. J Hazard Toxic Radioact Waste 18(3):04014013

44. Wang CT, Chou WL, Chung MH, Kuo YM (2010) COD removal from real dyeing wastewater by electro-Fenton technology using an activated carbon fiber cathode. Desalination 253:129-134

45. Mollah MYA, Schennach R, Parga JR, Cocke DL (2001) Electrocoagulation (EC) - science and applications. J Hazard Mater 84:29-41 
46. Park T, Lim JS, Lee Y, Kim S (2003) Catalytic supercritical water oxidation of wastewater from terephthalic acid manufacturing process. J Supercrit Fluids 26(3):201-213

47. Garg KK, Prasad B (2016) Treatment of multicomponent aqueous solution of purified terephthalic acid wastewater by electrocoagulation process: optimization of process and analysis of sludge. J Taiwan Inst Chem Eng 60:383-393

48. Thamer BJ, Voigt AF (1952) The spectrophotometric determination of overlapping constants of dibasic acids. The acid constants of isoththalic, terephthalic and chloranilic acids. J Phys Chem 56(2): 225-232

49. Kushwaha JP, Srivastava VC, Mall ID (2010) Studies on electrochemical treatment of dairy wastewater using aluminum electrode. Environ Energy Eng 57:2589-2598

50. Do JS, Yeh WC (1996) Paired electrooxidative degradation of phenol with in situ electrogenerated hydrogen peroxide and hypochlorite. J Appl Electrochem 26:673-678

51. Franza JA, Williamsa RJ, Floraa JRV, Meadowsa ME, Irwinb WG (2002) Electrolytic oxygen generation for subsurface delivery: effects of precipitation at the cathode and an assessment of side reactions. Water Res 36:2243-2254

52. Kallel M, Belaid C, Boussahel R, Ksibi M, Montiel A, Elleuch B (2009) Olive mill wastewater degradation by Fenton oxidation with zero-valent iron and hydrogen peroxide. J Hazard Mater 163(2-3): $550-554$
53. Watts RJ, Foget MK, Kong SH, Teel AL (1999) Hydrogen peroxide decomposition in model subsurface systems. J Hazard Mater 69(2): 229-243

54. Zhou M, Yu Q, Lei L, Barton G (2007) Electro-Fenton method for the removal of methyl red in an efficient electrochemical system. Sep Purif Technol 573:380-387

55. Pennizza M, Cerisola G (2008) Electrochemical degradation of methyl red using BDD and $\mathrm{PbO}_{2}$ anodes. Ind Eng Chem Res 47: 6816-6820

56. Pennizza M, Cerisola G (2007) Electrocatalytic materials for the electrochemical oxidation of synthetic dyes. Appl Catal B Environ 75:95-101

57. Nidheesh PV, Gandhimathi R (2012) Trends in electro-Fenton process for water and wastewater treatment: an overview. Desalination 299:1-15

58. Kurt U, Apaydin O, Gonullu MT (2007) Reduction of COD in wastewater from an organized tannery industrial region by electro-Fenton process. J Hazard Mater 143:33-40

59. Narayanan TSNS, Magesh G, Rajendran N (2003) Degradation of O-chlorophenol from aqueous solution by electro-Fenton process. Fresenius Environ Bull 12(7):776-780

60. Song G, Cao C, Chen SH (2005) A study on transition of iron from active into passive state. Corros Sci 47(2):323-339

61. ASTM (2011) Annual book of ASTM standard, standard test for $\mathrm{pH}$ of activated carbon, ASTM D 3838-05, Philadelphia PA, USA 